UDC 377/378.09:74/75(477)«18/193»

DOI https://doi.org/10.32840/1992-5786.2020.70-1.2

M. A. Boichenko

Doctor of Pedagogical Sciences, Associate Professor, Associate Professor of the Chair of Pedagogy of Sumy State Pedagogical University named after A. S. Makarenko

A. M. Nykyforov

Candidate of Pedagogical Sciences, Sculptor Self-employed

\title{
HOME SCHOOLING AS AN ALTERNATIVE TO INSTITUTIONAL FORMS OF TEACHING DECORATIVE AND FINE ARTS IN UKRAINE IN THE XIX - EARLY XX CENTURIES
}

The article is devoted to the analysis of peculiarities of home schooling in the context of the history of development of institutional and non-institutional forms of teaching decorative, applied and fine arts disciplines in the territory of Ukraine, which in the XI - early XX century was part of the Russian Empire. It is found out that during the period under study home schooling was a common form of education among the wealthy layers of the population of Ukraine as part of the Russian Empire: nobles, landowners, officials, clergy.

It is established that home tutors and home teachers carried out pedagogical activities in accordance with the legal framework of the Ministry of Public Education of the Russian Empire. Legal foundations of artistic disciplines formation were considered in the course of systematic analysis of a number of documents of the government department of education (statutes, decrees, orders, circulars, etc.), which were published on the pages of the popular at that time periodicals, such as: "Journal of the Ministry of Public education", "Provincial News" and others. It is found out that the education system reform by the efforts of the Ministry of Public Education was caused by inconsistency of the level of public school organization, necessity of updating of the pedagogical approaches, forms and methods, which significantly influenced expansion of the content of education (in particular artistic disciplines) both in the system of general education as a whole and in the system of home schooling in particular.

It is stated that the normative-legal documents concerning introduction of the subjects of artistic and decorative cycle in general education institutions were obligatory for pedagogical work of home teachers and home tutors. The application of gender approach in home schooling is shown, which indicates the division of tasks of the cycle of arts and crafts with compulsory needlework lessons for girls (embroidery, carving, work with beads) and lessons of traditional handicrafts mastering for boys (woodworking, carpentry, working with metal).

It is concluded that home schooling played a positive role in the formation of decorative arts teaching in the history of the national education development in the lands of Ukraine, which were part of the Russian Empire in the XIX - early XX century.

Key words: home schooling and upbringing, legal framework, introduction of decorative and fine arts lessons, home teachers, home tutors.

Introduction. The relevance of the study of the art education development history is determined by the priorities of the contemporary cultural and educational space and those transformations and adjustments that have taken place in the history of the national education system formation. The study of the positive pedagogical experience of introducing arts and crafts teaching into the system of art education of Ukraine in the XIX early $X X$ centuries is appropriate, as it will provide an opportunity to understand modern approaches to teaching and upbringing by means of traditional types of folk art.

Analysis of recent research and publications. Modern researchers (N. Averianov (2010), N. Balabust (2013), V. Vorozhbyt (2001), L. Harbuzenko (2016), O. Kovalchuk (2003), L. Kis (2012) and others) study the national art education development of the XIX early $X X$ centuries focusing on the issue of teaching traditional types of folk arts and crafts of Ukraine. Scientists O. Vlasiuk (2015), S. Kikto (2012), D. Kudinov (2016), V. Lypnyk (2003), Yu. Lopatenko (2015), I. Malynina (2005) and others indirectly touched upon the topic of teaching traditional crafts beyond classical institutional education. R. Shmahalo (2005) investigated the problem of the decorative art formation in the context of art education development in Ukraine from the standpoint of art science. The regional component of home schooling and upbringing in the history of national education has been studied by L. Antokhina (2001), N. Balabust (2013), O. Hulei (2019) and others.

The aim of the article is to analyze home schooling in the territory of Ukraine within the legal 
framework of the formation of decorative and fine arts education as an alternative to institutional forms of education of the XIX - early XX centuries.

Research results. The study has found out that in the XIX - early XX centuries a very popular form of education in the territory of Ukraine that was part of the Russian Empire was home schooling, which was spread among the wealthy people: nobles, landowners, officials and clergy [1]. The home tutor or teacher gave lessons to one or more children belonging to the same family and living in the same home environment. It should be noted that home tutors lived in homes where they worked, while private home teachers taught children on an hourly basis, on certain days [2, p. 5].

If before the beginning of the 1930 s such categories of teaching staff as "home tutor", "home teacher", "supervisor" (governor) carried out their pedagogical activity in accordance with the ministerial statutes of 1804 and 1828, then in July 1834 the Ministry of Public Education approved the document "Home tutors and teachers regulations" [3], which clearly defined such concepts as "home tutor", "home teacher", and set public requirements which these positions had to meet: responsibilities, educational qualifications, status, financial support, privileges, etc. [4].

It should be noted that artistic disciplines were introduced into the compulsory list of subjects, as evidenced by the "Regulations on the teachers of painting and drawing in gymnasiums and district schools" (1932) [5]. Undoubtedly, the abovementioned innovations were embodied in home schooling. Home schooling did not lose government's attention in the second half of the XIX century. Thus, the Decree of the Emperor of January 13, 1850 approved the image of a medal for rewarding home tutors and home teachers [6, p. 605]. On February 25, 1853, Emperor Mykola II issued a decree on pensions and one-off benefits for home tutors and teachers [7, p. 162].

According to N. Hurkina's research, spread of the social pedagogical movement was a distinctive feature of the mid XIX century. Issues of education and upbringing were discussed in the press, including newly created pedagogical journals that had appeared since the early 1960s [8]. Thus, a very popular among domestic intelligentsia was the Journal of the Ministry of Public Education, which published governmental orders, articles on pedagogy and sciences, reviews and bibliographies, and the chronicle of the educational work in the Russian Empire and abroad. These publications testify to the fact that the Ukrainian public was actively involved in the dissemination of education and culture (a major component of which was arts and crafts education) among various segments of the population.
It should be noted that after the abolition of serfdom (1861) the population of cities increased significantly. The rise of industrial potential, the growth of spiritual and material demands of society required both an increase in the scale of urban development and the provision of the population with decorative arts and crafts [9]. This necessitated development of a system of education institutions that would provide workers with necessary knowledge and skills in all fields of production, including arts and crafts, as well as pedagogical staff training in the field of artistic disciplines [10].

Now, in 1864, as a result of the introduction of the "Charter of gymnasiums and pro-gymnasiums subordinate to the Ministry of Public Education", there were introduced changes in the management of education institutions [11]. In Zemstvo provinces, they were removed from the provincial directorates of public schools and subordinate to county and provincial school councils. Each gymnasium had its own library with textbooks for students and manuals for teachers, as well as a set of visualization materials in science, history, geography, mathematics, drawing [12].

Accordingly, in 1863 and 1868, the tsarist government introduced a number of additions and amendments to the "Regulations on home tutors and teachers" (1834) to specify the status of these persons. It has been confirmed that the title of the "home tutor" was granted only to persons who had higher education [13]. According to a new regulation on women's gymnasiums (1870), the 8th (additional) pedagogical class was opened here. Students who completed elementary and 8th grade, and were awarded gold or silver medals, were awarded titles of home tutors, and those who did not have medals - home teachers. Both titles gave the right to teach in the relevant specialty in city schools and junior grades of gymnasiums, as well as to carry out educational work in families and private boarding schools.

It should be mentioned that the government constantly took care of home schooling, creating during the XIX century the legal basis for its comprehensive development and activities of home tutors and home teachers. Evidence of this are the decrees, orders and circulars, which set out clear and well-controlled state governance frameworks for the designated category of persons.

At the same time, it is important to emphasize that democratic reforms of all branches in the 60 s of the XIX century helped to expand the network of schools on the lands of Ukraine, which were part of the Russian Empire, in which drawing and handicraft lessons were introduced, that significantly influenced the content of the home form of education and upbringing.

It is worth noting that Zemstvo institutions actively participated in the process of formation of all forms of teaching decorative art in Ukraine in the second 
half of the XIX - early XX centuries. At the same time, the activities of Zemstvo self-governmentinstitutions in the context of the public education development were regulated by two provisions of 1871 [14] and 1874 [15]. Consequently, the rights of Zemstvos on participation in the education management were reduced to determining the content and order of reporting for the funds spent, presenting candidates for teaching positions, election of school trustees, which were maintained at the expense of Zemstvos. Management reports, estimates, and results of revisions, that were published in the "Provincial News", confirm these facts. According to the "Instruction for twoclass and one-class rural schools" (1875) the study of needlework (for girls), handicrafts (for boys), gardening, horticulture, beekeeping was foreseen if funds and pedagogical staff were available [16]. The introduction of such an innovation was supposed to be done at the expense of Zemstvo institutions or philanthropists.

At the beginning of the $X X$ century, the Ministry of Public Education actively prepared for the education system reform, which was caused by the inconsistency of the level of public school organization, the need to update pedagogical approaches, forms and methods [17]. According to the new regulations, the content of general education was expanded. The list of compulsory subjects included painting, drawing, singing, physical exercises, needlework, handicraft [18]. Thus, home-schooling classes included drawing lessons at the legislative level, as well as needlework (for girls) and folk crafts (for boys).

As N. Balabust rightly pointed out, non-formal home education existed as an alternative to formal institutional education, since it actually acquired the status of a fullfledged component of the educational sphere due to legislative, regulatory and pedagogical-methodological support, since training was carried out according to the relevant educational and methodological literature, approved by the Ministry of Public Education [19]. Therefore, we'd like to emphasize the fact that the normative-legal documents on the introduction of subjects of artistic and decorative cycle in general education institutions were obligatory for ensuring the educational process of home teachers and home tutors in the territory of Ukraine as part of the Russian Empire of the studied period.

According to L. Antokhina's research, we have an example of a description of home schooling conditions, which states that (...) the student's family lived in a large private house, a gymnasium, a carpentry and a locksmith workshops were equipped in the basement room for their son's study. Every day a trainer and two masters taught him. There was individually arranged a classroom with a desk, a blackboard, and a set for lessons with home teachers and home tutors. In addition, there was a large home library to educate all the children of the family [20]. Under such conditions, most children of the nobles, wealthy burghers and the bourgeoisie were educated. As we can see, L. Antokhina's study confirms the above-mentioned facts regarding teaching of traditional types of decorative arts by the home teachers (boys - carpentry, woodworking; girls - embroidery, beadwork, etching, etc.) [21].

Thus, home schooling of children of the wealthy layers of the population at the outlined stage of the national education development also played a positive role in the formation of teaching decorative arts on the lands of Ukraine in the XIX - early $\mathrm{XX}$ centuries.

Conclusions. Thus, the systems analysis of the literary sources and archival materials made it possible to conclude that home schooling in the territory of Ukraine that was part of the Russian Empire in the XIX - early XX centuries was developing on the background of social changes and reforms. The studied period of the process of introduction of decorative and fine arts teaching in the system of home schooling and upbringing of the studied period was distinguished by:

- desire for knowledge of all the segments of the population;

- expanding the network of educational establishments where drawing and handicraft lessons were introduced;

- requests from the wealthy layers of the population for the home form of education and upbringing;

- extension of the legal framework of the introduction of objects of artistic and aesthetic cycle in the educational process;

- popularity of home schooling for the wealthy layers of the population;

- using gender-based approaches in the homeschooling process (needlework for girls (embroidery, carving) and handicrafts for boys (woodworking, carpentry);

- training of pedagogical staff (home teachers and home tutors) in line with the general state development of public education;

- improvement of pedagogical and methodological foundations of providing home form of education and upbringing.

The results of a scientific search have revealed that:

- home teaching of decorative and fine arts on the lands of Ukraine in the XIX - early XX centuries developed as an alternative to institutional forms of education;

- home education and upbringing of children of the wealthy layers of the population was carried out in accordance with the program of the Ministry of Public Education of the Russian Empire, which approved teaching drawing and other subjects of decorative arts field at the legislative level. 
The study does not exhaust all the aspects of the formation of decorative arts teaching on the lands of Ukraine in the XIX - early XX centuries. Further exploration should focus on the use of traditional folk art elements in the educational process of national art schools of the specified period.

\section{References:}

1. Рождественский С.В. Материалы для истории учебных реформ в России в XVIII-XIX вв. Санкт-Петербург : Тип. Т-ва «Общественная польза», 1910. 395 с.

2. Об обучении в частных домах чтению, письму и арифрметике. Журнал Министерства народного просвещения. 1835. № 1. С. 5-6.

3. Положение о домашних наставниках и учителях. Журнал Министерства народного просвещения. 1834. 8 авг. С. 9-36.

4. Указы и циркуляр Министерства народного просвещения о выдаче свидетельств на звание домашней учительницы : Об оштрафовании учителей не имеющих свидетельств о праве преподавания. 1834 г. ДАХО (Державний архів Харківської області). Ф. 658. Оп. 1. Спр. 9.

5. Положение об учителях рисования и черчения в гимназиях и уездных училищах. СанктПетербург : Тип. Департамента народного просвещения. 1832. 22 с.

6. Об утверждении рисунка медали для награждения домашних наставников и учителей. Журнал Министерства народного просвещения. 1850. Ч. LXV. C. 605.

7. О пенсиях и единовременных пособиях домашним наставникам и учителям. Журнал Министерства народного просвещения. 1853. Ч. LXXVIII. C. 162-175.

8. Гуркина Н.К. История образования в России (Х-XX века) : учебное пособие. СанктПетербург : ГУАП, 2001. 64 с.

9. Гулей О. В. Нормативно-правове забезпечення декоративно-прикладного мистецтва як предмета педагогічного дослідження (перша половина XIX століття). Інноваційна педагогіка. 2019. Вип. 14. Т. 2. С. 36-39.

10.Молева Н.М., Белютин Э.М. Русская художественная школа второй половины XIX - начала XX века. Москва : Искусство, 1967. 567 с.
11.Устав гимназий и прогимназий ведомства Министерства народного просвещения, 1864 г. История педагогики в России : хрестоматия / сост. С.Ф. Егоров. Москва, 1999. С. 256-259.

12.Липник В. Н. Школьные рефрормы в России. Образование, 2003. № 5. С. 43-49.

13.0 домашних наставниках, учителях и учительницах. Журнал Министерства народного просвещения. 1868. Ч. CXXXVIII. С. 30-34.

14.Устав гимназий и прогимназий ведомства Министерства народного просвещения. Журнал Министерства народного просвещения. 1871. № 8. С. 42-73.

15.Положение о начальных народных училищах. Сборник постановлений по Министерству народного просвещения. 1874. Т. V. С. 262-282, T. VI. C. 223-234.

16.История России XIX - начала XX века / под ред. В.А. Федорова. Москва : Академия, 2004. $864 \mathrm{c}$.

17.Департамент полиции по вопросам касающимся объединения прогрессивных земских элементов с целью добиться демократических рефрорм. ЦДІАК України (Центральний державний історичний архів України, М. Київ). Ф. 442. Оп. 858. Спр. 172.

18.0 введении в гимназиях рисования в число обязательных предметов. 1877 г. ЦЦДІАК України. Ф. 707. Оп. 43. Спр. 51.

19.Балабуст Н.Ю. Підготовка педагогічних кадрів в Подільській губернії (друга половина XIX початок XX століття) : нормативно-правовий аспект. Педагогічний дискурс. 2013. № 14. C. 29-38.

20.Анохіна Л.С. 3 історії освіти у м. Вінниці (друга половина XIX - початок XX століття). Подільський телеграфр. 2001. № 12. С. 10-12.

21.Гулей О.В. Навчання декоративно-прикладного мистецтва Північно-Східної України в системі домашньої освіти другої половини XIX - початку XX століття. Perspectives et mise en oeuvre de l'innovation dans le domaine scientifique: collection de papiers scientifiques

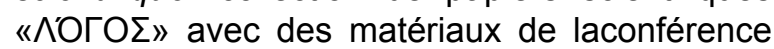
scientifique et pratique international (Genève, 20 septembre 2019). Genève, 2019. Vol. 1. C. $112-113$.

Бойченко М. А., Никифоров А. М. Домашнє навчання як альтернатива інституційним формам навчання декоративного й образотворчого мистецтва в Україні XIX - початку XX століття

Запропоновану розвідку присвячено аналізу становлення й функціонування домашнього навчання в контексті історії розвитку інституційних та позаінституційних фрорм навчання мистецьких дисциплін галузі декоративно-прикладного й образотворчого мистецтва на території України, яка в XIX на початку XX століття знаходилася під владою Російської імперії. З'ясовано, що в досліджуваний період домашнє навчання було поширеною формою освіти в середовищі заможних верств населення підросійської України: дворян, поміщиків, чиновників, священнослужителів.

Установлено, що домашні наставники й домашні вчителі здійснювали педагогічну діяльність згідно з нормативно-правовою базою Міністерства народної освіти Російської імперії. Правові засади становлення мистецьких дисциплін розглянуто в ході системного аналізу низки документів урядового 
відомства освіти (у статутах, указах, розпорядженнях, положеннях, циркулярах тощо), які оприлюднено на сторінках тогочасних популярних періодичних видань, як-от: «Журнал Министерства народного просвещения», «Губернские ведомости» та інші. Виявлено, що реформування системи освіти зусиллями Міністерства народної освіти зумовлювалося невідповідністю рівня організації державної школи, необхідністю оновлення педагогічних підходів, фоорм і методів, що суттєво вплинуло на розширення змісту навчання як загальної освіти в цілому, так і системи домашньої фоорми навчання в галузі мистецьких дисциплін зокрема. Констатовано, що нормативно-правові документи стосовно впровадження предметів художнього й декоративного циклу в закладах загальної середньої освіти були обов'язковими у змісті педагогічної роботи домашніх учителів і домашніх наставників. Показано застосування гендерного підходу в домашній освіті, на що вказує розподіл завдань предметів циклу декоративно-прикладного мистецтва з обов'язковими уроками рукоділля для дівчат (вишивання, гаптування, витинання, робота з бісером) і занять із освоєння традиційних ремесел для хлопців (деревообробка, столярна справа, робота з металом).

Зроблено висновок щодо того, що домашнє навчання відіграло позитивну роль у становленні навчання декоративного мистецтва в історії розвитку вітчизняної освіти на землях підросійської України XIX - початку XX століття.

Ключові слова: домашнє навчання й виховання, нормативно-правове підгрунтя, запровадження уроків декоративного й образотворчого мистецтва, домашні вчителі, домашні наставники. 